\title{
Correction: Emergency care surveillance and emergency care registries in low-income and middle-income countries: conceptual challenges and future directions for research
}

Mowafi H, Ngaruiya C, O'Reilly G, et al. Emergency care surveillance and emergency care registries in low-income and middle-income countries: conceptual challenges and future directions for research. BMJ Global Health 2019;4:e001442. doi: 10.1136/bmjgh-2019-001442

The authors want to alert the readers on the incorrect affiliation published for the co-author Andres M Rubiano which is now updated in the published version.

Open access This is an open access article distributed in accordance with the Creative Commons Attribution 4.0 Unported (CC BY 4.0) license, which permits others to copy, redistribute, remix, transform and build upon this work for any purpose, provided the original work is properly cited, a link to the licence is given, and indication of whether changes were made. See:https://creativecommons.org/licenses/by/4.0/.

(C) Author(s) (or their employer(s)) 2019. Re-use permitted under CC BY. Published by BMJ.

BMJ Global Health 2019;4:e001442corr1. doi:10.1136/bmjgh-2019-001442corr1

A) Check for updates 